\title{
Literature Survey and Research Agenda of Risk Determinants in Indian Equities and Machine Learning
}

\author{
Pradeep Kumar Rangi ${ }^{1} \&$ P. S. Aithal ${ }^{2}$ \\ ${ }^{1}$ Research Scholar, College of Management \& Commerce, Srinivas University, Mangalore, \\ India \\ OrcidID: 0000-0002-2052-9054; E-mail: pradeep.rangi@gmail.com \\ ${ }^{2}$ Professor, College of Management \& Commerce, Srinivas University, Mangalore, India \\ OrcidID: 0000-0002-4691-8736; E-mail: psaithal@gmail.com
}

Area/Section: Business Management.

Type of the Paper: Review based Research Analysis.

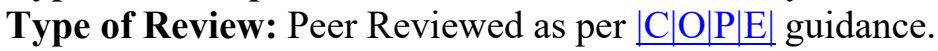

Indexed in: OpenAIRE.

DOI: http://doi.org/10.5281/zenodo.4590131.

Google Scholar Citation: IJMTS.

\section{How to Cite this Paper:}

Rangi, Pradeep Kumar, \& Aithal P. S., (2021). Literature Survey and Research Agenda of Risk Determinants in Indian Equities and Machine Learning. International Journal of Management, Technology, and Social Sciences (IJMTS), 6(1), 83-109. DOI: http://doi.org/10.5281/zenodo.4590131.

International Journal of Management, Technology, and Social Sciences (IJMTS)

A Refereed International Journal of Srinivas University, India.

(C) With Author.

CrossRef DOI: https://doi.org/10.47992/IJMTS.2581.6012.0131

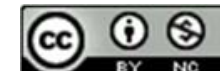

This work is licensed under a Creative Commons Attribution-Non-Commercial 4.0 International License subject to proper citation to the publication source of the work.

Disclaimer: The scholarly papers as reviewed and published by the Srinivas Publications (S.P.), India are the views and opinions of their respective authors and are not the views or opinions of the SP. The SP disclaims of any harm or loss caused due to the published content to any party.
\end{abstract}




\title{
Literature Survey and Research Agenda of Risk Determinants in Indian Equities and Machine Learning
}

\author{
Pradeep Kumar Rangi ${ }^{1} \&$ P. S. Aithal ${ }^{2}$ \\ ${ }^{1}$ Research Scholar, College of Management \& Commerce, Srinivas University, Mangalore, \\ India \\ OrcidID: 0000-0002-2052-9054; E-mail: pradeep.rangi@gmail.com \\ ${ }^{2}$ Professor, College of Management \& Commerce, Srinivas University, Mangalore, India \\ OrcidID: 0000-0002-4691-8736; E-mail: psaithal@gmail.com
}

\begin{abstract}
Notwithstanding the financial slowdown and severity of the Coronavirus pandemic during 2020, several retail investors ventures directly to the secondary equities market, setting off gigantic purchasing. A review of SEBI data indicates that over 6 million new dematerialization accounts between April and September 2020 are about 125 percent growth on year on year basis. At the same time, data reported by AMFI shows net outflows from equity funds by retail investors. These data points indicate that retail investors may have opted to invest using direct stock investments instead of relying on the equity mutual fund manager. Equity Investment is a dynamic process requiring and require considering different variables in selecting and, more importantly, avoiding stocks. The cornerstone of wealth creation is to invest in stores at a price considerably smaller than their intrinsic value. The very foundation of creating long-term wealth using equities is deeply embedded. One is buying businesses at a price substantially below its intrinsic value (intrinsic value indicates the entity's future cash flows after estimating the number of accounting risk, macro-economic, managerial, and behavioral risk determinants). This Literature review, therefore, is organized to cover Behavioral, Accounting, Macro-economic, Volatility, and Management theories and Forecasting and ML techniques for clustering, predictions, and classification to support risk decisions using different models, e.g., ARIMA, LSTM, VAR, Facebook Prophet, ARCH and GARCH family models, etc. The literature review also establishes that the concept of risk is highly subjective and is perceived by different investors differently; it is not always entirely objective and outside the beliefs, cognitive and socio-cultural considerations requiring careful assessment before making investment decisions. However, examining the critical risk indicators would allow investors to make a more informed decision. The research gap and identified agenda for further review were defined and assessed using valuable ABCD and SWOT management frameworks. Consequently, the literature investigation findings are analyzed by offering recommendations for creating a comprehensive research agenda pertinent to long-term equity investors in the Indian Equity market.
\end{abstract}

Keywords: Risk, Financial Statement analysis, Timeseries, Panel-data models, Altman's zscore

\section{INTRODUCTION :}

The stock market is generally referred to as a public marketplace to facilitate issuance, buying, and selling stocks or equities. Stocks or equities represent ownership or fractional ownership in an entity. Stock markets and exchanges also serve as a critical catalyst for promoting transparency and good governance or corporate governance, thus providing a vital decision-making tool to different stakeholders. A Strong, liquid, and efficiently operating stock market is essential for stimulating economic development and entrepreneurship in developing economies, as it provides businesses quick access to capital and at the same time allows investors with an opportunity to gain share in publicly listed companies. The stock market also serves as an essential indicator to the policy owners for making 
policy decisions. In today's age of technology, digitalized onboarding, and paperless KYC verifications, it's surprisingly fast (takes about 10 minutes) and easy (from the comfort of your home or when you are riding a bus) to get started with buying and selling stocks investing in stocks. Usually, investors confuse this ease of buying and selling stocks with the ease with which wealth can be created using equity. A review of SEBI data indicates that over 6 million new dematerialization accounts between April and September 2020, about 125 percent growth on year on year basis. At the same time, data reported by AMFI shows net outflows from equity funds by retail investors. These data points indicate that retail investors may have experimented with direct stock trading and moved away from the professional fund managers.

Equity Investment is a dynamic process requiring and require considering different variables in selecting and, more importantly, avoiding stocks. Stock and indexes are highly volatile and are affected by several factors, including firms' performance, decisions, macro-economic aspects, perceptions of stakeholders, etc. The prices of a share market are also influenced by demand and supply. It is critical to understand individual stock characteristics and various risk determinants essential in making an effective and efficient investment decision.

The application of Machine learning, AI, and Deep Learning for stock prediction is attracting a lot of interest from scholars and industry. Several researchers have presented research in stock performance prediction, and a long list of stock prediction techniques has been developed over the years. These prediction techniques can broadly be classified into three broad groups, i.e., Fundamental analysis (based on financial information), Technical analysis (based on historical stock prices and volume, etc.), and Sentiment analysis (based on articles, tweets, searches, etc.). However, the consistency and accuracy of these predictions are still debatable. There are two critical theories related to stock market prediction: Efficient Market Hypothesis (EMH) and Second Random Walk Theory (RWT). EMG explains that the prices reflect all the accessible information about the stock or index, and hence it is not possible to outperform. EMH, however, may exist in Weak, Semi-Strong, or Strong form. RWT assumes that prices are random (and highly fluctuating), hence impossible to predict stock prices. There, however, are research work supporting and challenging these theories. Buying and investing in stock is an entrepreneurial venture, i.e., investing in the company's future and past is only an indication of its managerial, governance, and execution competence. Investment, therefore, is a confluence crossfunctional skill including financial, administrative understanding, and entrepreneurial vision.

Following are some of the algorithms and techniques applied to stock prices, including for Clustering (K-Mean, Self-Organizing Maps, and Hierarchical Clustering), Prediction (Random Forest, Support Vector Machine, Multilayer perception, Long Short-Term Memory, Recurrent Neural Network, Genetic Algorithm, K Nearest Neighbor, Support Vector Regression, Monte Carlo Simulation, Artificial Neural Network, Classification, and Regression Tree, Gaussian Process, Generalized Regression Neural Network, Back Propagation Neural Network, Logistic Regression, Hidden Markov Model) and Classification (Support Vector Machine and K Nearest Neighbor). The Literature review demonstrates that one of the critical reasons for the failure of ML stock prediction projects is (a) Arbitrary selection of stock or index for forecasting, i.e., ignoring accounting, macro, and other factors (ignoring domain expertise of investment), (b) Exchange data related to stocks and indexes are nonstationary time-series and prediction (i.e., precise) is impossible, (c) the future of prices of stocks depends on several factors (internal, external and behavioral), some of these factors cannot be measured but require entrepreneurial assessment and vision while the ML techniques mainly focused on mathematical and logical models and finally deficient pre-processing of stock data.

The very foundation of creating long-term wealth using equities is deeply embedded in that one is buying businesses at a price substantially below its intrinsic value (intrinsic value indicates future cash flows of the entity after estimating the number of accounting risk, macro-economic, managerial, and behavioral risk determinants). The ML then supports both to form and support an investment decision. The lower the intrinsic or embedded value high is the margin (popularly known as the margin of safety on investment). 
This Literature review therefore is organized to cover following factors impacting risk determinants of equity investment of different aspects of risk:

a) Risk management including behavioral aspects, e.g., cognitive, and socio-cultural hypotheses [1][9]

b) Financial statements related factors, i.e., critical financial statement ratios [6], [10]-[30]

c) Macro-economic factors, Volatility, and returns correlation and causation [31]-[43]

d) Management theories, Behavioral and mental models and other factors to assess fundamentals of business, competition, and longevity of growth [44]-[66], [67]

e) Forecasting and ML techniques in price clustering, predictions and classification to support risk decisions using different models e.g. ARIMA, LSTM, VAR, Facebook Prophet, ARCH and GARCH family models etc. [68]-[77], [78].

\section{OBJECTIVES OF SCHOLARLY REVIEW :}

This Literature review aims to study the risk determination characteristics of different risk measures, i.e., financial or accounting, macro-economic, managerial decisions, and other eco-system-related factors that impact these risk measurements. The study, therefore, attempts to present assortments of research papers that provide various aspects of investment risk decisions with specific reference to equities both within and outside India. Broadly, the objectives of this Literature review are as under:

a) To examine, study and familiarize with various risk determinants for equities and their relationship with investment returns.

b) To identify the Research Gap and advancement opportunities based on the existing literature study.

c) To construct the Research Agenda.

\section{RESEARCH METHODOLOGY OF LITERATURE REVIEW :}

For this study, various databases, including ShodhGanga, Google Scholar, CORE, Bielefeld Academic Search Engine (BASE), Directory of Open Access Journals (DOAJ), PubMed, E-Theses Online Service (EThOS), Social Science Research Network (SSRN), Academia, WorldWideScience, Semantic Scholar, Public Library of Science (PLOS), Research Gate and MPRA, have been searched to establish relevant scholarly articles, thesis, and conference proceedings. The Literature review further enhanced by including books and internet resources to cover investment practitioners' writeups and other established knowledge in investment risk determinants. The Literature review approach adopted in this study constitutes of two key components. First, the literature supports determining progress, challenges, and gaps and presents advancement opportunities in the proposed research area. Second, review of classical [1]-[9] and modern theoretical and practical work including philosophies, technological advances such as Artificial Intelligence, Machine Learning, Analytical tools and models to support study [68]-[77], and gain opportunity to leverage multi-disciplinary established knowledge to further the scope of the study. Adopting this approach has allowed us to examine, published literature and different aspects of the risk measurements systematically including, Risk management, Financial statements, Macro-economic factors, Volatility, Management theories, Forecasting and ML techniques

Both the research gap and identified agenda for further review were defined and assessed using valuable $\mathrm{ABCD}$ [79], [80] and SWOT management frameworks [81], [82].

\section{SCHOLARLY REVIEW OF RESEARCH LITERATURE :}

An investor's primary objective is to generate satisfactory returns throughout investment tenure and preserve wealth by identifying and making informed risk decisions, consistent with investors' risk appetite [1]. The concept of risk and risk management has been studied and applied in several traditional and modern investment, projects, science, corporate and technology fields. Despite such a wide application, there is no unified understanding, perception, and agreed definition of the risk and its assessment. In investment usage, the term Risk means and associated with adverse or loss outcomes, though some practitioners consider it in a broader sense to include and define as uncertainty, including opportuning to gain from such uncertainty. Risk is highly subjective and is perceived by different investors differently; it is not always entirely objective and outside the beliefs, cognitive and socio- 
cultural considerations requiring careful assessment before making investment decisions. [2]-[7]. Markowitz's paper acknowledges the subjectivity inherent in what constitutes risk by noting that the article does not cover how an investor constructs a risk likelihood conviction [4]. Almost every investor or potential investor has their risk appetite, investment motivations, and investing style, and therefore there can be no one set of risk determinants in the form of a checklist. However, examining the critical risk indicators would allow investors to make a more informed decision. This paper has broadly examined literature that identifies and supports identifying risk determinants using accounting ratios, macro-economic factors, management frameworks related matters, other factors, and application of prediction models, applying it before every investment decision.

The investment approach broadly may be either economy level, i.e., Top-down, or stock-specific and based on companies' fundamentals, i.e., Bottom-up approach. However, neither the Top-down and nor Bottom-up investing approach is self-sufficient and hence should be used to complement each other to reach an investment decision; hence for this study, we have included both firm-specific factors and macro-economic and eco-system-related factors where such businesses operate. The researchers have considered several accounting ratios, i.e., Balance-Sheet, Income Statement, and Cash-flows and related information to establish an indication of risk on stocks performance, volatility, and longevity and concern the business.

A positive relationship between risk and return has been a cornerstone of the investment principle, i.e., investors would be willing to undertake higher risk in anticipation of higher returns. The relationship has been widely tested using the beta of capital assets pricing model (CAPM) as the risk measure, and the results achieved are contradictory [7], [83]. Bowman published the relationship with accounting data and pointed out that paradoxical negative relationship managers accept higher risk while expecting lower returns [6]. Bowman's work (popularly known as "Bowman's Paradox") propelled research interest in accounting variable-based risk-return relationship. Some of the critical accounting ratios assessed by researchers in the recent publications include Valuation related ratios, Return on Capital, Equity and Assets, Retained Income/ Earnings, Liquidity related ratios, Leverage related ratios, Earnings per Share, Price Earnings Ratio, Dividend payout Ratios, and yields, Asset Turnover and other efficiency ratios, Other performance and efficiency ratios [6], [10]-[30]. The accounting ratios help the investor gain critical insight into the business failure risk; this is popularized through the initial publication of discriminant analysis Z-Score [23], o-score model based on a combination of weighted ratios based on four fundamental determinants, i.e., firms' size, financial structure, performance, and liquidity [25] and furthered by more complex and advanced tools including logit, probit, neural network, and linear probability models, etc [84], [85], [86].

In addition to accounting information and volatility, research scholars have studied and presented shreds of evidence of the causal relationship between macro-economic variables and stock prices. These results and publications provide a vital indication to identify risk determinants that Stock investors may consider in addition to the theory outlined by the CAPM model. These published works also promoted developing and examining various equity models, e.g., Arbitrage Pricing Theory (APT) and Present Value Model (PVM). Several macro-economic factors impact stock return and the determination of future cash flow to calculate the present value or intrinsic value. The different macro-economic factors and their causal relationship and correlation with stock return studies by scholars include GDP, deficits, inflation, money flow, production indexes, manufacturing indexes, COVID-19 impacts, global commodity prices, e.g., Gold, Oil, and other expected and unexpected macro-economic events [34][43].

Forecasting equity returns and volatility is a useful tool to help mitigate portfolio risk. In past decade or so, researchers have presented several forecasting techniques using ML to improve the accuracy of forecasts and inform risk decisions. Paper also examines the predictive strength of Linear, Nonlinear, and Hybrid models presented by various researchers. The existing work in literature on stock price prediction may broadly be grouped under OLS or simple Regressing, Panel data Methods [26], [87], Timeseries Models (such as ARIMA) [72], [74], [88], Granger Causality [31], [43], [33]) and Machine Learning and Deep learning [68], [71], [76], [84], [69], [76]. The results from these papers indicate that 
no single model could be applied uniformly to all markets, given the complexity of different factors that may impact the stock return.

It is also critical to understand the business or stock under consideration for investment and related risk decisions from an overall eco-system and environmental perspective. Some of the critical factors impacting risk determinants proposed by several authors are a type of Business model, which may impact profitability and competitiveness of business or entity, e.g., B2B, B2C [50]. Assess longevity of the business, e.g., using mental models such as Lyndi effect [51]. perform DuPont Analysis [53], [54]. Establish the category and quality of business proposition i.e. Great, the Good and the Gruesome, i.e., avoiding investments in equities of business which requires significant and frequent capital for growth and earns minimal returns [52]. Assess the competition as same may have an impact on competitive advantage period and longevity of growth period (e.g., Michael Porter's five forces framework) [55] and assessing the strength of value migration between industry, businesses, and companies, which may be a critical risk determinant in making investment decision [59]. The list presented is illustrative only, research work in the area is very extensive.

Another critical risk consideration is Behavioral aspects, i.e., understanding how investors invest, challenging assumptions of homo economicus, or economic man assumptions [89]. Researchers present several empirical pieces of evidence to demonstrate the impact of cognitive psychology, i.e., how people think and the market inefficiencies, i.e., Mis-valuation of markets [90]. The study identified cognitive psychology in factors such as Heuristics (rule of thumb) [91], Prospect (i.e., subjective and influenced by value system including mental accounting) [92], [93] and Herding (i.e., behaviors to follow other's reactions) [93].

Table 1: The list of scholarly publications related to risk determinants in equities related to accounting information, macro-economic factors, equity valuation, management frameworks and forecasting models.

\begin{tabular}{|l|l|l|l|}
\hline $\begin{array}{l}\text { S. } \\
\text { No. }\end{array}$ & $\begin{array}{l}\text { Research } \\
\text { Area }\end{array}$ & Focus Area & References \\
\hline 1 & $\begin{array}{l}\text { Risk } \\
\text { Management }\end{array}$ & $\begin{array}{l}\text { In the book, security analysis author outlined a clear distinction } \\
\text { between speculation and investment activities. The book is } \\
\text { considered the centerpiece of valuation. }\end{array}$ & {$[1]$} \\
\hline 2 & $\begin{array}{l}\text { Risk } \\
\text { Management }\end{array}$ & $\begin{array}{l}\text { Paper explores cognitive and socio-cultural hypotheses that } \\
\text { contrast the interpretation and meaning of risk, which are not } \\
\text { always profoundly empiric but are perceived and expressed in } \\
\text { society and are continuously changing. There are claims from both } \\
\text { sides that risk analysis is an objective assessment and equally } \\
\text { strong contrast that it is more of a context-bound; there is still an } \\
\text { aspect of both judgments, sentiment, and personality. }\end{array}$ & {$[3]$} \\
\hline 3 & $\begin{array}{l}\text { Risk } \\
\text { Management }\end{array}$ & $\begin{array}{l}\text { Markowitz's portfolio selection model suggests that investors } \\
\text { make their investment choices based on returns and spreads of } \\
\text { risk. However, the paper also acknowledges the subjectivity } \\
\text { inherent in what constitutes risk by noting that the article does not } \\
\text { cover how an investor constructs a risk likelihood conviction. }\end{array}$ & [5] \\
\hline 4 & $\begin{array}{l}\text { Risk } \\
\text { Management }\end{array}$ & $\begin{array}{l}\text { The Utility Theory points out that investors prepared to embrace } \\
\text { the risk must get a superior return or reward for taking the risk. } \\
\text { However, several following research papers dispute and } \\
\text { empirically shown, using both volatility and financial statement } \\
\text { evidence, that such a relationship does not materially exist and, in } \\
\text { a few instances, is an inverse relationship. }\end{array}$ & {$[5],[9]$} \\
\hline 5 & $\begin{array}{l}\text { Risk } \\
\text { Management }\end{array}$ & $\begin{array}{l}\text { The study elaborates business risk (different risk measures) and its } \\
\text { relationship with a return across companies within industries. }\end{array}$ & {$[6]$} \\
\hline
\end{tabular}




\begin{tabular}{|c|c|c|c|}
\hline 6 & $\begin{array}{l}\text { Efficient } \\
\text { Market } \\
\text { Hypothesis }\end{array}$ & $\begin{array}{l}\text { Paper explains what may be defined as an efficient market is, i.e., } \\
\text { the price reflects all the available information. It identified market } \\
\text { efficiency has three forms weak form, semi-strong and strong. } \\
\text { Fama was awarded for his work with a Nobel Prize in } 2013\end{array}$ & [7] \\
\hline 7 & $\begin{array}{l}\text { Efficient } \\
\text { Market } \\
\text { Hypothesis }\end{array}$ & $\begin{array}{l}\text { This paper evaluates the application and effectiveness of Random } \\
\text { Walk in an efficient market to predict stock returns in the Nigeria } \\
\text { exchange }\end{array}$ & [8] \\
\hline 8 & $\begin{array}{l}\text { Forecasting } \\
\text { Models }\end{array}$ & $\begin{array}{l}\text { CNN, i.e., Convolutional Neural Network is used for forecasting } \\
\text { the future NIFTY index. Paper presented detailed results for } \\
\text { regression models indicating CNN (based multivariate } \\
\text { forecasting) model is the most effective in predicting Nifty values. }\end{array}$ & [68] \\
\hline 9 & $\begin{array}{l}\text { Forecasting } \\
\text { Models }\end{array}$ & $\begin{array}{l}\text { LSTM regression models are utilized to forecast future NIFTY } 50 . \\
\text { The results indicate that the LSTM-based univariate model uses } \\
\text { one-week prior data as input is most accurate to predict the Nifty } \\
\text { price time series. }\end{array}$ & [69] \\
\hline 10 & $\begin{array}{l}\text { Forecasting } \\
\text { Models }\end{array}$ & $\begin{array}{l}\text { The PCA analysis was used for respective stock prices and } \\
\text { continued using the multivariate approach to make the necessary } \\
\text { predictions. Performance metrics such as RMSE, MAPE } \\
\text { demonstrates that the model envisaged satisfies the model goal. }\end{array}$ & {$[70]$} \\
\hline 11 & $\begin{array}{l}\text { Forecasting } \\
\text { Models }\end{array}$ & $\begin{array}{l}\text { The Paper explained the efficiency of three popular forecasting } \\
\text { methods, including machine learning domain, Monte Carlo and } \\
\text { linear regression, and Autoregressive modeling by forecasting a } \\
\text { PSU bank's stock prices using all the three models. }\end{array}$ & [71] \\
\hline 12 & $\begin{array}{l}\text { Forecasting } \\
\text { Models }\end{array}$ & $\begin{array}{l}\text { The ARIMA forecasting model is utilized for making stock price } \\
\text { prediction using daily closing prices for } 246 \text { trading days using } \mathrm{R} \\
\text { software. The results suggest that the ARIMA model has a strong } \\
\text { potential for short-term prediction. }\end{array}$ & [72] \\
\hline 13 & $\begin{array}{l}\text { Forecasting } \\
\text { Models }\end{array}$ & $\begin{array}{l}\text { This Paper attempts to evaluate the Volatility concerning Sensex } \\
\text { daily data for three years. Volatility modeling is done by the } \\
\text { ARCH and GARCH family models. }\end{array}$ & [73] \\
\hline 14 & $\begin{array}{l}\text { Forecasting } \\
\text { Models }\end{array}$ & $\begin{array}{l}\text { In the study ARIMA model utilized. A material spikes in the } \\
\text { correlogram of ACF and PACF observed, and many models have } \\
\text { been framed taking different AR and MA terms for each selected } \\
\text { company. Best model advised based on Volatility, adjusted R- } \\
\text { squared, and AIC }\end{array}$ & [74] \\
\hline 15 & $\begin{array}{l}\text { Forecasting } \\
\text { Models }\end{array}$ & $\begin{array}{l}\text { This Paper proposes new return forecasting models and suggested } \\
\text { that the forecasting accuracy can be enhanced by better model } \\
\text { specification without introducing new variables. Genetic } \\
\text { programming is adopted as a new model with nonlinearity. } \\
\text { Finally, it compares performance against AR-family models. }\end{array}$ & [75] \\
\hline 16 & $\begin{array}{l}\text { Forecasting } \\
\text { Models }\end{array}$ & $\begin{array}{l}\text { This Paper evaluates attention-based LSTM to predict stock price } \\
\text { movement in addition to price data, financial tweets, and technical } \\
\text { indicators utilized for US stock related data. The model suggests } \\
\text { that tweets between market close and open have more predictive } \\
\text { strength. }\end{array}$ & {$[76]$} \\
\hline 17 & $\begin{array}{l}\text { Forecasting } \\
\text { Models - } \\
\text { ARIMA, } \\
\text { LSTM and }\end{array}$ & $\begin{array}{l}\text { Paper utilizes ARIMA, LSTM, and Facebook prophet are used for } \\
\text { the stock price predictions. Paper explains the use of K-Means } \\
\text { clustering to choose a cluster and validate algorithm predictability } \\
\text { using processed data. }\end{array}$ & [77] \\
\hline
\end{tabular}




\begin{tabular}{|c|c|c|c|}
\hline & $\begin{array}{l}\text { Facebook } \\
\text { prophet }\end{array}$ & & \\
\hline 18 & $\begin{array}{l}\text { Forecasting } \\
\text { Models }\end{array}$ & $\begin{array}{l}\text { Paper assessed different models available to forecast changes in } \\
\text { stock market prices (especially nonlinear models). Other papers } \\
\text { also highlighted the importance and relevance of hypotheses } \\
\text { related to efficient markets. }\end{array}$ & [17] \\
\hline 19 & $\begin{array}{l}\text { Financial } \\
\text { Statements }\end{array}$ & $\begin{array}{l}\text { Paper describes the relationship between different risk } \\
\text { assessments across sectors and businesses with varying standards } \\
\text { of performance. The Paper also considers that as management tries } \\
\text { solutions that are not industry risk standards, its impacts the risk } \\
\text { premium that the company enjoys. }\end{array}$ & $\begin{array}{l}{[10]} \\
{[21]}\end{array}$ \\
\hline 20 & $\begin{array}{l}\text { Financial } \\
\text { Statement }\end{array}$ & $\begin{array}{l}\text { Application of Panel data analysis studied through the review of } \\
\text { this research work, i.e., though looking the convergence of growth } \\
\text { explored through panel analysis techniques including explaining } \\
\text { the relationship between stock returns and various accounting } \\
\text { variables. }\end{array}$ & $\begin{array}{l}{[13]} \\
{[14]}\end{array}$ \\
\hline 21 & $\begin{array}{l}\text { Financial } \\
\text { Statement }\end{array}$ & $\begin{array}{l}\text { These research papers outlined and demonstrated the impact of the } \\
\text { firm related variables, i.e., accounting ratios and information } \\
\text { (geographies and markets outside India). Critical financial and } \\
\text { accounting information included operations including cash } \\
\text { conversions, leverage, performance, efficiency (functional), and } \\
\text { stock market-related ratios. }\end{array}$ & $\begin{array}{l}{[15]} \\
{[16]} \\
{[95]} \\
{[18]} \\
{[19]}\end{array}$ \\
\hline 22 & $\begin{array}{l}\text { Financial } \\
\text { Statement }\end{array}$ & $\begin{array}{l}\text { Paper evaluates if corporate governance of an entity impacts and } \\
\text { demonstrates a relationship with stock return. Based on data from } \\
\text { Taiwan entities and exchange degree of governance regime } \\
\text { depicted relationship with stock returns. }\end{array}$ & {$[20]$} \\
\hline 23 & $\begin{array}{l}\text { Financial } \\
\text { Statement }\end{array}$ & $\begin{array}{l}\text { Paper evaluates various financial analysis tools, including } \\
\text { standard size analysis, comparative statement, trend, networking } \\
\text { capital, cash flow, cost volume profit analysis. }\end{array}$ & [22] \\
\hline 24 & $\begin{array}{l}\text { Financial } \\
\text { Statements }\end{array}$ & $\begin{array}{l}\text { Paper introduces a z-score model based on accounting data, i.e., } \\
\text { several financial ratios to gain indication on corporate bankruptcy } \\
\text { prediction. The second Paper reviewed in this respect included } \\
\text { work on expanding the model to assess and predict the financial } \\
\text { health of UK entities. The approach adopted had the use of } \\
\text { discriminatory regressors. }\end{array}$ & [23] \\
\hline 25 & $\begin{array}{l}\text { Financial } \\
\text { Statement }\end{array}$ & $\begin{array}{l}\text { The Paper proposed an o-score model based on a combination of } \\
\text { weighted ratios based on four fundamental determinants, i.e., } \\
\text { firms' size, financial structure, performance, and liquidity. }\end{array}$ & [25] \\
\hline 26 & $\begin{array}{l}\text { Financial } \\
\text { Statement }\end{array}$ & $\begin{array}{l}\text { The paper demonstrates that the use of accounting measures or } \\
\text { risk related measures is based on the underlying conditions/ } \\
\text { environment and the objective of making such decisions. The } \\
\text { Paper also examined the relationship between these two risk type } \\
\text { measures with references to banks in Asia. The results of research } \\
\text { depict that accounting measures are significant to predict capital } \\
\text { market-related risks for these banks. }\end{array}$ & [26] \\
\hline 27 & $\begin{array}{l}\text { Financial } \\
\text { Statement }\end{array}$ & $\begin{array}{l}\text { The Paper demonstrates that the data from the financial statement } \\
\text { or accounting data helps recognize overvalued or undervalued } \\
\text { share prices and help forecast Beta for the security. }\end{array}$ & [27] \\
\hline
\end{tabular}




\begin{tabular}{|c|c|c|c|}
\hline 28 & $\begin{array}{l}\text { Financial } \\
\text { Statement }\end{array}$ & $\begin{array}{l}\text { The Paper demonstrates the difference between the } z \text {-score } \\
\text { accounting based model (i.e., z score) and market-based risk } \\
\text { decision models are not statistically significant. The paper also } \\
\text { highlights that the } \mathrm{z} \text { score model is slightly more precise compared } \\
\text { to market risk-based measures. }\end{array}$ & [28] \\
\hline 29 & $\begin{array}{l}\text { Financial } \\
\text { Statement }\end{array}$ & $\begin{array}{l}\text { These multiple research papers examined firms related variables, } \\
\text { albeit risk measures (accounting ratios) across various industries } \\
\text { in India, time horizons, and their impact on the stock price } \\
\text { performance. Key measures include: } \\
\text { a. Valuation related ratios, e.g., Book Value per share or } \\
\text { Dividend payout } \\
\text { b. Return on Capital, Equity and Assets, Retained Income/ } \\
\text { Earnings } \\
\text { c. Liquidity related ratios } \\
\text { d. Leverage related ratios } \\
\text { e. Earnings per share } \\
\text { f. Price Earnings Ratio } \\
\text { g. Dividend payout Ratios and yields } \\
\text { h. Asset Turnover and other efficiency ratios } \\
\text { i. Other performance and efficiency ratios }\end{array}$ & $\begin{array}{l}{[29]} \\
{[30]} \\
{[11]} \\
{[12]}\end{array}$ \\
\hline 30 & $\begin{array}{l}\text { Macro- } \\
\text { Economic and } \\
\text { other factors }\end{array}$ & $\begin{array}{l}\text { The paper assessed the relationship between macro-economic } \\
\text { factors and stock prices using Granger Causality and } \\
\text { Cointegration. The study demonstrated that this factor (especially } \\
\text { interest rate) influence stock prices and returns. }\end{array}$ & [31] \\
\hline 31 & $\begin{array}{l}\text { Macro- } \\
\text { Economic and } \\
\text { other factors }\end{array}$ & $\begin{array}{l}\text { Paper explores the relationship between stock returns in Nigeria } \\
\text { and macro factors of the country such as GDP, deficits, inflation, } \\
\text { money flow, production indexes, etc. }\end{array}$ & [32] \\
\hline 32 & $\begin{array}{l}\text { Macro- } \\
\text { Economic and } \\
\text { other factors }\end{array}$ & $\begin{array}{l}\text { The paper evaluates weekly economic data (including exchange } \\
\text { rate and gold price) and stock returns (Sensex index) using } \\
\text { correlation and multiple regression models for the period } 2008 \text { to } \\
2009\end{array}$ & [36] \\
\hline 33 & $\begin{array}{l}\text { Macro- } \\
\text { Economic and } \\
\text { other factors }\end{array}$ & $\begin{array}{l}\text { Papers evaluate the impact of exchange, interest, and inflation } \\
\text { rates on Nairobi's stock prices. Research results show that these } \\
\text { factors have a significant effect on stock prices. }\end{array}$ & [37] \\
\hline 34 & $\begin{array}{l}\text { Macro- } \\
\text { Economic and } \\
\text { other factors }\end{array}$ & $\begin{array}{l}\text { The paper evaluates and investigates the relationship between } \\
\text { China and India stock prices and four economic variables, i.e., } \\
\text { crude price, inflation, production data, and money supply. Various } \\
\text { tests performed include unit root and cointegration etc. }\end{array}$ & [38] \\
\hline 35 & $\begin{array}{l}\text { Macro- } \\
\text { Economic and } \\
\text { other factors }\end{array}$ & $\begin{array}{l}\text { This research paper further analyzed various macro-economic } \\
\text { factors and their impact on stock prices in the Indian context. The } \\
\text { factors analyzed include. } \\
\text { a. Change in stock prices because of COVID-19 (pre and post- } \\
\text { impact), i.e., event-related analysis. } \\
\text { b. Quantile regression to examine index returns pre- and post- } \\
\text { recession using macro-economic factors for both India and } \\
\text { China } \\
\text { c. Monetary unanticipated shocks appear to have significantly } \\
\text { asymmetrically lagged effects on stock prices. } \\
\text { d. The impact of both unexpected and expected macro events on } \\
\text { stock Findings demonstrates contradiction of the Efficient } \\
\text { market hypothesis in the Indian context. }\end{array}$ & $\begin{array}{l}{[39]} \\
{[40]} \\
{[41]} \\
{[42]} \\
{[43]} \\
{[33]} \\
{[34]} \\
{[35]}\end{array}$ \\
\hline
\end{tabular}




\begin{tabular}{|c|c|c|c|}
\hline & & $\begin{array}{l}\text { e. Factors including product index, price index, foreign } \\
\text { institution investors, etc. using Correlation, Granger test and } \\
\text { VECM } \\
\text { f. Relationship study related to cryptocurrency and stock index } \\
\text { in India and China. } \\
\text { g. relationship between exchange rate and stock prices. Granger } \\
\text { shows no relationship between exchange rates and the stock } \\
\text { market and a weak positive relationship demonstrated by the } \\
\text { correlation } \\
\text { h. Evaluate the causality and correlation between US economic } \\
\text { policy and stock indexes in India and China. Results suggest } \\
\text { unidirectional Granger causality in a medium and extended } \\
\text { period; however, absent in the short term. }\end{array}$ & \\
\hline 36 & $\begin{array}{l}\text { PCA-Principal } \\
\text { component } \\
\text { analysis }\end{array}$ & $\begin{array}{l}\text { Paper used the PCA statistical method to summarize many factors } \\
\text { of data to few factors and displayed the same using perpetual map } \\
\text { to translate profitable stocks. }\end{array}$ & $\begin{array}{l}{[44]} \\
{[45]}\end{array}$ \\
\hline 37 & $\begin{array}{l}\text { Equity } \\
\text { Valuation - } \\
\text { CAPM, } \\
\text { Intrinsic Value }\end{array}$ & $\begin{array}{l}\text { Paper examines CAPM and its relevance and suitability for Indian } \\
\text { stocks to validate risk and return relationship and assess CAPM's } \\
\text { valuation strength in the Indian context. }\end{array}$ & {$[46]$} \\
\hline 38 & $\begin{array}{l}\text { Equity } \\
\text { Valuation - } \\
\text { Free Cash } \\
\text { flow to Equity }\end{array}$ & $\begin{array}{l}\text { Paper demonstrates the use of free cash flow to equity value model } \\
\text { proposed in Damodaran (2006) in Applied Corporate Finance. The } \\
\text { study further combined with a growth model to determine the } \\
\text { present value of the stock. }\end{array}$ & {$[47]$} \\
\hline 39 & $\begin{array}{l}\text { Compounding. } \\
\text { Volatility and } \\
\text { ROE }\end{array}$ & $\begin{array}{l}\text { Paper explains that average or mean return may be defined as the } \\
\text { mean of perpetually compounded return when making an } \\
\text { investment decision. ROE, i.e., profitability, is proposed for } \\
\text { estimating equity premium rather than volatility }\end{array}$ & {$[49]$} \\
\hline 40 & $\begin{array}{l}\text { Business type } \\
\text { B2B, B2C }\end{array}$ & $\begin{array}{l}\text { Paper examines the impact on a firm's valuation due to different } \\
\text { managerial actions for the internet companies engaged in B2B e- } \\
\text { commerce. }\end{array}$ & {$[50]$} \\
\hline 41 & Mental Model & $\begin{array}{l}\text { Taleb explained in the book that life expectancy extends with time, } \\
\text { for the non-perishable can be Lindy. The metal model provides for } \\
\text { a heuristic about the length of non-Perishable items. }\end{array}$ & {$[51]$} \\
\hline 42 & $\begin{array}{l}\text { Mental Model } \\
\text { - Great, the } \\
\text { Good and the } \\
\text { Gruesome }\end{array}$ & $\begin{array}{l}\text { Among other things, the paper explains the business as Great, the } \\
\text { Good, and the Gruesome, as Warrant Buffett explained, e.g., } \\
\text { Gruesome business requires significant and frequent capital for } \\
\text { growth and earns minimal returns. The article explains Warren B' } \\
\text { investment methodology by looking at value investing, the margin } \\
\text { of safety, and the intrinsic worth of a company. }\end{array}$ & {$[52]$} \\
\hline 43 & $\begin{array}{l}\text { DuPont } \\
\text { Analysis }\end{array}$ & $\begin{array}{l}\text { Paper presented measured financial performance ROE, ROA } \\
\text { applying the DuPont analyses. DuPont analysis provides a critical } \\
\text { indication towards judging the operating financial performance of } \\
\text { the firm. }\end{array}$ & {$[53]$} \\
\hline 44 & $\begin{array}{l}\text { DuPont } \\
\text { Analysis }\end{array}$ & $\begin{array}{l}\text { Paper compares financial performance of retail firms using } \\
\text { modified DuPont model of financial ratio analysis. Results show } \\
\text { that firms adopting differentiating strategy may not essentially } \\
\text { yield high returns on a net operating basis. }\end{array}$ & {$[54]$} \\
\hline 45 & $\begin{array}{l}\text { Michael } \\
\text { Porter's five } \\
\text { forces } \\
\text { framework }\end{array}$ & $\begin{array}{l}\text { Paper provides a set of templates for applying Michael Porter's } \\
\text { five forces framework for industry analysis. Therefore, it provides } \\
\text { a visually compelling, user-friendly format for analyzing }\end{array}$ & {$[55]$} \\
\hline
\end{tabular}




\begin{tabular}{|c|c|c|c|}
\hline & & $\begin{array}{l}\text { competitive advantages for individual firms, i.e., Rivalry, New } \\
\text { entrants, Substitution, Bargaining power of buyers and suppliers. }\end{array}$ & \\
\hline 46 & $\begin{array}{l}\text { Sustainable } \\
\text { Value Creation }\end{array}$ & $\begin{array}{l}\text { The paper explains and provides the importance of sustainable } \\
\text { value creation. The article highlights that it is critical to evaluate a } \\
\text { firm's economic performance relative to capital cost, not merely } \\
\text { relative to its competitors. }\end{array}$ & {$[57]$} \\
\hline 47 & $\begin{array}{l}\text { Competitive } \\
\text { advantage } \\
\text { Period }\end{array}$ & $\begin{array}{l}\text { Paper explains the Competitive advantage period, i.e., the number } \\
\text { of years a company is expected to generate excess returns on } \\
\text { incremental investments and provides a critical tool to the } \\
\text { valuation and has a role in linking valuation theory and practice. }\end{array}$ & {$[96]$} \\
\hline 48 & $\begin{array}{l}\text { Value } \\
\text { Migration }\end{array}$ & $\begin{array}{l}\text { This research work covered value migration to sustainable } \\
\text { business models of companies operating in the capital market's } \\
\text { digital economy. Paper demonstrates new trends and challenges in } \\
\text { the digital economy concerning sustainability requirements in the } \\
\text { context of value migration on the capital market. }\end{array}$ & {$[58]$} \\
\hline 49 & $\begin{array}{l}\text { Equity } \\
\text { Valuation } \\
\text { Models }\end{array}$ & $\begin{array}{l}\text { The publication examines and evaluates how value flows between } \\
\text { industries, between companies, and between business designs } \\
\text { within a company resulting in an outflow of shareholders value } \\
\text { from and between businesses. }\end{array}$ & {$[59]$} \\
\hline 50 & $\begin{array}{l}\text { Equity } \\
\text { Valuation } \\
\text { Models }\end{array}$ & $\begin{array}{l}\text { Using six different valuation models, i.e., Price Earning, Price } \\
\text { Book Ohlson, DDM, CAPM, and Excess Return, this paper } \\
\text { presents an approach to value banking stocks in India using its } \\
\text { significance in terms of both predictive strength and its accuracy } \\
\text { of valuation using AI neural network. }\end{array}$ & {$[56]$} \\
\hline 51 & $\begin{array}{l}\text { Equity } \\
\text { Valuation } \\
\text { Models }\end{array}$ & $\begin{array}{l}\text { The paper presents a framework in which accounting could be } \\
\text { connected and utilized for estimating expected stock returns. }\end{array}$ & {$[60]$} \\
\hline 52 & $\begin{array}{l}\text { Equity } \\
\text { Valuation } \\
\text { Models }\end{array}$ & $\begin{array}{l}\text { The paper demonstrates the model formed using valuation-related } \\
\text { multiples strongly correlate to the stock price in emerging prices } \\
\text { throughout } 20 \text { years study. }\end{array}$ & {$[61]$} \\
\hline 53 & $\begin{array}{l}\text { Equity } \\
\text { Valuation - } \\
\text { P/E Ratio }\end{array}$ & $\begin{array}{l}\text { This paper examines } \mathrm{P} / \mathrm{E} \text { earning models and helps summarize } \\
\text { calculation and usage options. }\end{array}$ & {$[62]$} \\
\hline 54 & $\begin{array}{l}\text { Equity } \\
\text { Valuation - } \\
\text { P/S Ratio }\end{array}$ & $\begin{array}{l}\text { This paper demonstrates free cash flows to equity and the price to } \\
\text { sales under the Greece financial GAAPs standards. }\end{array}$ & {$[63]$} \\
\hline 55 & $\begin{array}{l}\text { Equity } \\
\text { Valuation - } \\
\text { Cash flow and } \\
\text { Accrual }\end{array}$ & $\begin{array}{l}\text { This study examines preference towards the use of cash flow- } \\
\text { based valuation over the accrual-based model valuation model. } \\
\text { The results show (based on the Chi-square test) that the use of both } \\
\text { the models in combination could enhance the valuation results }\end{array}$ & {$[64]$} \\
\hline 56 & $\begin{array}{l}\text { Equity } \\
\text { Valuation - } \\
\text { EV/EBIT } \\
\end{array}$ & $\begin{array}{l}\text { The article explains how the EV/EBIT ratio is more effective and } \\
\text { how it differs from PE and EV/ EBITDA metrics for the valuation } \\
\text { of stocks in technology sectors. }\end{array}$ & {$[65]$} \\
\hline 57 & $\begin{array}{l}\text { Equity } \\
\text { Valuation - } \\
\text { PEG Ratio }\end{array}$ & $\begin{array}{l}\text { This article evaluates PEG, i.e., price/earnings to growth for future } \\
\text { aggregate returns and economic fundamentals. The proxy } \\
\text { developed in the report shows that it outperforms aggregate PEG } \\
\text { ratios and the cross-section beta-premium estimate. }\end{array}$ & {$[66]$} \\
\hline 58 & $\begin{array}{l}\mathrm{ABCD} \\
\text { Framework }\end{array}$ & $\begin{array}{l}\text { The author proposed a useful ABCD framework based on four } \\
\text { constructs a) Advantages, b) Benefits, c) Constraints, and d) } \\
\text { Disadvantages. The framework considers all the determinants in }\end{array}$ & $\begin{array}{l}{[79]} \\
{[80]}\end{array}$ \\
\hline
\end{tabular}




\begin{tabular}{|c|c|c|c|}
\hline & & $\begin{array}{l}\text { critical areas by examining material issues and identifying the } \\
\text { essential elements. }\end{array}$ & \\
\hline 59 & $\begin{array}{l}\text { SWOT } \\
\text { Framework }\end{array}$ & $\begin{array}{l}\text { This paper presents a literature review on SWOT and examines its } \\
\text { effectiveness of situation analysis in the areas requiring strategic } \\
\text { planning. }\end{array}$ & $\begin{array}{l}{[81]} \\
{[82]}\end{array}$ \\
\hline 60 & Other Factors & $\begin{array}{l}\text { These papers analyzed other factors such as stock pledging, the } \\
\text { split of stocks, stock liquidity, and ownership concentration on a } \\
\text { given stock's stock returns. The following are critical outcomes } \\
\text { demonstrated by the papers. } \\
\text { a. Stock volatility and adverse impact on the value and long-term } \\
\text { performance identified wherein the cases were relatively } \\
\text { large, pledging. } \\
\text { b. Favorable (significant) stock price movement because of } \\
\text { splits around the day when firms announced the stock split. } \\
\text { The results also assessed various popular split ratios and their } \\
\text { impact on price. } \\
\text { c. Empirical results show a direct causal relationship between } \\
\text { firms' value and liquidity primarily from the improved } \\
\text { operational level performance. } \\
\text { d. Ownership concentration and stock returns: Evidence from } \\
\text { family firms in India }\end{array}$ & $\begin{array}{l}{[97]} \\
{[98]} \\
{[99]} \\
{[100]}\end{array}$ \\
\hline 61 & Volatility & $\begin{array}{l}\text { ARCH, i.e., Autoregressive Conditional Heteroskedastic process, } \\
\text { was introduced in 1982. The second paper explained and } \\
\text { presented empirical example related to the volatility of the } \\
\text { inflation }\end{array}$ & $\begin{array}{l}{[101]} \\
{[102]}\end{array}$ \\
\hline 62 & Volatility & $\begin{array}{l}\text { This paper utilized ARCG and GARCH technique to study the } \\
\text { impact of index futures (newly introduced) on cash segment or } \\
\text { spot volatility for both Nifty and Sensex. }\end{array}$ & [103] \\
\hline 63 & Volatility & $\begin{array}{l}\text { Econometric models including VAR, Univariate and Multivariate } \\
\text { GARCH utilized. Results demonstrated a co-movement between } \\
\text { SG, HK, JP, US, and UK. The study also indicated a likely } \\
\text { spillover of volatility from the smaller market to the significant } \\
\text { demand. }\end{array}$ & [104] \\
\hline 64 & Volatility & $\begin{array}{l}\text { Studies relationship between the stock \& nominal currency. The } \\
\text { E-GARCH model, as proposed by Nelson in } 1991 \text { is utilized to } \\
\text { demonstrate a connection. The results show a positive relationship } \\
\text { for one index while not for the other. }\end{array}$ & [105] \\
\hline 65 & $\begin{array}{l}\text { Volatility and } \\
\text { Forecasting } \\
\text { Models }\end{array}$ & $\begin{array}{l}\text { Paper assessed different models available to forecast changes in } \\
\text { stock market prices (especially nonlinear models). Other papers } \\
\text { also highlighted the importance and relevance of hypotheses } \\
\text { related to efficient markets. }\end{array}$ & {$[17]$} \\
\hline 66 & $\begin{array}{l}\text { Volatility and } \\
\text { Forecasting } \\
\text { Models }\end{array}$ & $\begin{array}{l}\text { The Paper explores the asymmetric (quantile causality) and a } \\
\text { cross-sectional relationship of market mood and consumer } \\
\text { sentiment, stock return, and Volatility in the Indian context. With } \\
\text { the stock returns and Volatility in India. Results reported } \\
\text { indicating that investor sentiment causes stock returns at extreme } \\
\text { quantiles. }\end{array}$ & [106] \\
\hline 67 & $\begin{array}{l}\text { Equity } \\
\text { Valuation - } \\
\text { Earning and } \\
\text { Book value }\end{array}$ & $\begin{array}{l}\text { The article employs the Ohlson model, and results show that the } \\
\text { book value of equity is more relevant than earning-based } \\
\text { valuation. }\end{array}$ & [107] \\
\hline
\end{tabular}




\begin{tabular}{|c|c|c|c|}
\hline 68 & $\begin{array}{l}\text { Equity } \\
\text { Valuation - } \\
\text { Return on } \\
\text { Capital, } \\
\text { Invested } \\
\text { Capital and } \\
\text { Earnings } \\
\text { (ROC/ROCI/ } \\
\text { ROE) } \\
\end{array}$ & $\begin{array}{l}\text { Paper examines both cash flow and accounting measures of excess } \\
\text { returns and suitability of such information to forecast for the } \\
\text { future. }\end{array}$ & {$[108]$} \\
\hline 69 & $\begin{array}{l}\text { Forecasting \& } \\
\text { Accounting } \\
\text { Information }\end{array}$ & $\begin{array}{l}\text { Corporate bankruptcy prediction logit, probit, neural network and } \\
\text { linear probability models }\end{array}$ & $\begin{array}{l}{[84]} \\
{[85]} \\
{[86]}\end{array}$ \\
\hline 70 & $\begin{array}{l}\text { Behavioral } \\
\text { Finance }\end{array}$ & $\begin{array}{l}\text { These research papers presented Behavioral Finance studies in } \\
\text { stock decisions including } \\
\text { a. Challenges assumptions of homo economicus, or economic } \\
\text { man assumptions } \\
\text { b. Impact of cognitive psychology } \\
\text { c. Heuristics (rule of thumb) } \\
\text { d. Prospect (i.e., subjective and influenced by value system } \\
\text { including mental accounting) } \\
\text { e. Herding (i.e., behaviors to follow other's reactions) }\end{array}$ & $\begin{array}{l}{[88]} \\
{[89]} \\
{[90]} \\
{[91]} \\
{[92]}\end{array}$ \\
\hline 71 & Piotroski score & Piotroski score case study from Mexico & [109] \\
\hline
\end{tabular}

\section{IDENTIFIED ISSUES IN RISK MEASUREMENTS AND COMMON PITFALLS :}

Based on the literature review, five areas that influence the risk component and measurement include Accounting information and ratios, Macro-economic indicators, Eco-system and competition in which a business operate, forecasting, e.g., simple regression, panel data, and time series and Cognitive psychology, illusions and bias (risk determination may not always be objective). The accounting performance measures may be tracked back to the beginning of the 20th Century, accounting ratios and information after that applied in several forms to establish a relationship between performance and return [110], the approach was further supported by the use of cash flow discounting, net present value and internal rate of returns [111], [112], cost of capital valuation[113], [114] techniques and models. These accounting ratios also helped develop a variant including shareholder value-added, economic value-added, and economic profits based on shareholders valuation approach. These indicators also serve as risk determinants for potential investment and have gained popularity as risk decision metrics among investors [115].

The critical accounting ratios that may help investors establish investment risk determinants may include the following categories, (a) Balance Sheet Ratio including Debtor Days, Inventory Turnover, Fixed Asset Turnover, Debt/Equity, Return on Equity, Return on Capital Employed, Return on Invested Capital, (b) Income Statement Ratios including Sales Growth, Expenses Growth, Sustainable Growth Rate, Gross Profit Growth, Profit Before Tax Growth, Net Profit Growth, Dividend Growth, Dividend Payout, Gross Margin, Operating Margin, Profit Before Tax Margin, and Net Margin, (c) Cash flow ratios, Free Cash Flow, Operating Cash Flow Growth, Free Cash Flow Growth, FCF/Sales, CFO/Total Assets, $\mathrm{CFO} /$ Total Debt, Cash Interest Coverage and $\mathrm{CFO} /$ Capex, and (d) Combination of Ratios including Altman Z-score, Piotroski Score and DuPont [6], [10]-[30], [109].

The macro-dynamics of stock returns and arbitrage pricing theory has an underlying assumption that assumes returns are generated and influenced by several macroeconomic factors. The number of research and related empirical studies in finance and economics has evidenced and demonstrated causation and correlation (relationship) between equity returns prices and the macroeconomic variables. 
Several accounting valuation models require interest rates as an essential valuation consideration. These macroeconomic components are an essential consideration in forming risk decisions about future cashflow and equity return expectations. Based on the literature review, some of the critical macroeconomic factors identified include, Inflation rate, exchange rates, Gross Domestic Product (GDP), unemployment rates, industrial and production data, consumption, and money supply employment rate, exchange rate, GDP, Inflation, commodity prices (e.g., Crude oil and metals) and money supply [31][43].

Predicting or forecasting equity prices with a high degree of accuracy could easily be stated as most challenging task given number of factors both actual and behavioral. With the growth of AI, machine learning and deep learning, and artificial intelligence, with limited coding lines, a very efficient statistical model can be accessible. However, the prediction task is still challenging as though machine learning can be attributed to statistics and coding, what is equally important is being aware of fundamentals that may impact the predictability of stock or index under consideration. Forecasting equity returns and volatility is a useful tool to help mitigate portfolio risk. The examination of literature review demonstrates that the researchers have presented several forecasting techniques using machine learning to improve forecasts' accuracy and inform risk decisions. We have attempted to study the predictive strength of both Linear, Nonlinear, and Hybrid models to forecast stocks and indexes' equity performance through this literature review. The existing work in literature on stock price prediction may broadly be grouped under OLS or simple Regressing, Panel data Methods [26], [87], Timeseries Models (such as ARIMA) [72], [74], [88], Granger Causality [31], [43], [33]) and Machine Learning and Deep learning[68], [71], [76], [84], [69], [76]. Any indiscriminate use of pre-processing techniques and ML codes and models will only yield indiscriminate results. Therefore, it is critical to assess if the data in question is predictable or is it nuanced, with the signal-to-noise ratio being systemically low. Several factors may impact the accuracy of predictions. These factors include an arbitrary selection of stock or index for forecasting, i.e., ignoring accounting, macro, and other factors, ignoring individual stock's impact on the portfolio, and finally, deficient pre-processing of stock data.

Underlying the investment decision and risk decisions or selection of risk determinants are the psychological bias experienced by investors. Psychological bias experienced by investors led to wrong decision making and fatal losses. The number of empirical evidences suggest that cognitive bias and psychological bias behavior occur in nearly all informants however at the same time undertaking a systematic approach, experience and insight of capital markets and awareness of existing bias reduce bias behavior that could be raising the return [67].

\section{IDEAL SOLUTION AND PRESENT STATUS :}

The Ideal solution may include providing a framework for decision-making, which encompasses various risk considerations in the decision-making process. The accounting performance measures [110], [111], [112], [113], [114] including shareholder value-added, economic value-added, and economic profits based on shareholders valuation approach. These indicators also serve as risk determinants for potential investment and have gained popularity as risk decision metrics among investors[115]. The risk determinants using accounting ratios may depend on the type of stakeholder and the purpose of such investigation. [6], [10]-[30], [109]. In addition to accounting factors, the ideal solution is also expected to assess or provide for assessing macroeconomic components as an essential consideration in forming risk decisions about future cashflow and equity return expectations. [31][43]. Another key consideration is to assess predictive strength of Linear, Nonlinear, and Hybrid models to forecast stocks and indexes' equity performance through this literature review. The existing work in literature on stock price prediction may broadly be grouped under OLS or simple Regressing, Panel data Methods [26], [87], Timeseries Models (such as ARIMA) [72], [74], [88], Granger Causality [31], [43], [33]) and Machine Learning and Deep learning [68], [71], [76], [84] [69], [76]. Finally, Underlying the investment decision and risk decisions or selection of risk determinants are the psychological bias experienced by investors. Therefore, the ideal framework for assessing or recognizing psychological bias experienced by investors led to wrong decision-making and catastrophic losses [67]. 


\section{SUMMARY OF RISK DETERMINATS IN EQUITIES BASED ON LITERATURE SURVEY:}

The key risk determinants identified from systematic review of literature is summarized in Table 2.

Table 2: Summary of key risk determinants identified from systematic review of literature.

\begin{tabular}{|c|c|c|c|}
\hline $\begin{array}{l}\text { S. } \\
\text { No. }\end{array}$ & Group & Risk Determinants & References \\
\hline 1 & $\begin{array}{l}\text { Accounting } \\
\text { Information }\end{array}$ & $\begin{array}{l}\text { a) Balance Sheet Ratio including Debtor Days, Inventory } \\
\text { Turnover, Fixed Asset Turnover, Debt/Equity, Return on } \\
\text { Equity, Return on Capital Employed, Return on Invested } \\
\text { Capital. } \\
\text { b) Income Statement Ratios including Sales Growth, Expenses } \\
\text { Growth, Sustainable Growth Rate, Gross Profit Growth, Profit } \\
\text { Before Tax Growth, Net Profit Growth, Dividend Growth, } \\
\text { Dividend Payout, Gross Margin, Operating Margin, Profit } \\
\text { Before Tax Margin, Net Margin and } \\
\text { c) Cash flow ratios, Free Cash Flow, Operating Cash Flow } \\
\text { Growth, Free Cash Flow Growth, FCF/Sales, CFO/Total Assets, } \\
\text { CFO/Total Debt, Cash Interest Coverage and CFO/Capex } \\
\text { d) Combination of Ratios including Altman Z-score, Piotroski } \\
\text { Score and DuPont. }\end{array}$ & $\begin{array}{l}{[6],[10]-} \\
{[30],[109]}\end{array}$ \\
\hline 2 & $\begin{array}{l}\text { Macro- } \\
\text { Economic }\end{array}$ & $\begin{array}{l}\text { Inflation rate, Exchange rates, Gross Domestic Product (GDP), } \\
\text { Unemployment rates, Industrial and Production index, } \\
\text { Consumption, and Money supply, Employment rate, Exchange } \\
\text { rate, GDP, Commodity prices (e.g., Crude oil and metals) and } \\
\text { other expected and unexpected economic factors. }\end{array}$ & {$[31]-[43]$} \\
\hline 3 & $\begin{array}{l}\text { Management } \\
\text { Frameworks } \\
\text { and } \\
\text { approaches }\end{array}$ & $\begin{array}{l}\text { Business type B2B, B2C, Mental Model, Mental Model - } \\
\text { Great, the Good and the Gruesome, DuPont Analysis, Michael } \\
\text { Porter's five forces framework, Sustainable Value Creation, } \\
\text { Competitive advantage Period and Value Migration. }\end{array}$ & {$[44]-[66]$} \\
\hline 4 & $\begin{array}{l}\text { Forecasting } \\
\text { Models }\end{array}$ & $\begin{array}{l}\text { OLS or simple Regressing, Panel data, Timeseries Models and } \\
\text { Machine Learning and Deep learning. Time series models } \\
\text { include: } \\
\text { a. Benchmark forecasting i.e., Naive Forecast, Seasonal } \\
\text { Naïve, Drift model, Linear Trend, Random Walk } \\
\text { Geometric Random Walk } \\
\text { b. Exponential smoothing i.e., Simple Exponential } \\
\text { Smoothing, Holt's linear trend, Holt-Winter Exponential } \\
\text { Smoothing } \\
\text { c. ARIMA Family i.e., Autoregressive (AR), Moving average } \\
\text { (MA), ARMA, ARIMA, SARIMA, ARIMAX } \\
\text { d. Advanced models i.e., Regression, Fast Fourier Transform } \\
\text { (FFT), Vector Autoregressive model (VAR), ARCH, Deep } \\
\text { Learning/RNN/LSTM, Panel data models, System } \\
\text { dynamics modeling (SD), Agent-based Modeling (ABM) }\end{array}$ & $\begin{array}{l}{[26],[87],} \\
{[72],[74],} \\
{[88],[31],} \\
{[43],[33]} \\
{[68],[71],} \\
{[76],[84]} \\
{[78]} \\
{[68]-[77]}\end{array}$ \\
\hline 5 & $\begin{array}{l}\text { Behavioral } \\
\text { factors }\end{array}$ & $\begin{array}{l}\text { a. Heuristics (rule of thumb) } \\
\text { b. Prospect (i.e., subjective and influenced by value system } \\
\text { including mental accounting) } \\
\text { c. and Herding (i.e., behaviors to follow other's reactions) } \\
\text { d. Overconfidence Bias } \\
\text { e. Confirmation Bias } \\
\text { f. Anchoring Bias } \\
\text { g. Loss aversion }\end{array}$ & $\begin{array}{l}{[91],[92],} \\
{[93]}\end{array}$ \\
\hline
\end{tabular}




\section{IDENTIFIED RESEARCH OPPORTUNITIES FROM THE LITERATURE REVIEW :}

Based on our literature review, it is evident that Stock is an area of interest across Accounting, Economics, Social Science, Management, and Computer Science. Most of the studies focused on Indian markets have considered only two or more and not all the five components identified through this Literature review, i.e., Accounting information and ratios, Macro-economic indicators, Eco-system and competition in which a business operate, forecasting, e.g., simple regression, panel data, and time series and Cognitive psychology, illusions and bias (risk determination may not always be objective).

The Literature review also demonstrates that one of the critical reasons for the failure of ML stock prediction projects is an arbitrary selection of Stock or index for forecasting, i.e., ignoring accounting, macro, and other factors, ignoring individual Stock's impact on the portfolio, and deficient preprocessing of stock data. Literature review reveals that there is an opportunity to investigate risk determinants holistically, i.e., establishing predictability of Indian equities (both Index and Sector) using accounting, macro-economic and other facts. Rank type of business models, competitive landscape (stocks), which make returns more predictable. Finally, applying ML and Deep learning algorithms based on the stock universe was identified through predictability analysis and comparative analysis to demonstrate strength and accuracy.

Further, based on our literature review of the Indian markets-related study, an opportunity to develop an easy-to-use checklist combining the above five components' study may help existing and potential long-term investors, research scholars, and industry in making risk decisions related investments.

The proposed study is not intended to make Stock or investment recommendations but to provide a systematic approach that an investor may adopt to make more risk-informed decisions or evaluate its opportunity.

\section{RESEARCH AGENDA FOR RISK DETERMINANTS IN INDIAN EQUITIES SPECIFIC STUDY :}

Based on this Literature review, the primary author proposed the following risk agenda for a more detailed study that shall benefit existing and potential long-term investors, research scholars, and industry:

(1) To investigate accounting information as a critical risk determinant to establish predictability of Indian equities (both Index and Sector).

(2) To further investigate by including macro-economic factors impacting predictability of Indian equities (both Index and Sector).

(3) To investigate and rank type of businesses models, competitive landscape (stocks) which make returns more predictable.

(4) To Forecasting using ML and Deep learning algorithms and presenting a comparative analysis to demonstrate strength and accuracy.

(5) To provide an indicative checklist of various risk determinants to support investment decisions.

\section{SWOT ANALYSIS OF RESEARCH AGENDA :}

\section{Strength:}

(1) The Objective focuses on all the five components, i.e., Accounting information and ratios, Macroeconomic indicators, Eco-system, and competition in which a business operates, forecasting, cognitive psychology, illusions, and bias.

(2) The agenda caters to study specific to Indian equities, including sectoral representation.

(3) The agenda provides a mechanism to rank the category of stocks, i.e., based on various factors, thereby enhancing pre-processing of time-series before application to ML algorithms.

(4) Agenda provides a comparative analysis to demonstrate the crucial ML model's strength and accuracy in the Indian context.

(5) Agenda provides an indicative checklist of various risk determinants to support investment decisions. 


\section{Weakness:}

(1) The risk cannot be entirely objective and is influenced by individual perception

(2) The contrary evidence from various researchers to theories EMH and Random Walk analysis makes it extremely difficult to rely on one set of checklist or sequence of analysis for all the type of stocks, markets, and time frames

(3) Variations in Suitability of risk timeframe and return objectives may vary from individual to individual and from time to time for the same individual

(4) Investment in equities requires an assessment of the company's future and, therefore, a confluence of different skills, including Finance, Economy, Management, Industry, and entrepreneurial vision.

(5) The research work output cannot and should not be used as investment advice or stock recommendation to buy, sell, or otherwise make an equities-related decision.

\section{Opportunities:}

(1) Opportunity to present a study encompassing various factors that may influence risk decisions and act as risk determinants. This attempts to eliminate a prominent reason for the failure of models, i.e., arbitrary selection of stock and indexes

(2) The Objective will contribute to investor awareness and allows investors to use the findings as comfortable reference material to supplement risk decisions.

(3) The agenda will help users with a mechanism to rank the category of stocks, i.e., based on various factors based on empirical evidence to demonstrate what type of businesses could be a consistent wealth creator over the years.

\section{Threats:}

(1) Equities are dynamic and impacted by multiple factors. Therefore, there is no one size fit checklist

(2) Risk determinants and results from the model are not always objectively interpreted, given the interpretation may depend on the individual risk profile of the investor and perception of risk and reward.

(3) Certain fundamental factors, including accounting, are lag indicators, and such lag events period may not consist across periods and timeframe

(4) Any other new inventions or discoveries or innovations in the field are disrupting the agenda's execution.

(5) Some of the risk determinants may be subject to manipulation and should be applied in conjunction with forensic accounting principles.

(6) Random-Walk Hypothesis assumes financial markets efficiency. A bubble in stock and asset class in different timeframes suggests that the efficiency hypothesis is questionable, making predictions using risk determinants.

\section{FINAL RESEARCH PROPOSAL IN CHOSEN TOPIC :}

After considering the research opportunities identified in this paper through analysis of existing research literature, the following is proposed as the final research proposal:

11.1 Title:

Risk Determinants in Indian equities and Machine Learning

\subsection{Purpose :}

As outlined in the opportunities section, there is an opportunity to assess risk determinants in Indian equities in a more holistic manner to include all the five components identified through this Literature review, i.e., Accounting information and ratios, Macro-economic indicators, Eco-system and competition in which a business operate, forecasting, and Cognitive psychology, illusions, and bias. The study will discuss risk determinants to include all the key factors. Further, it will propose a methodology to eliminate or reduce the pre-processing errors from an arbitrary selection of stock and index for ML algorithms. The study will finally present an easy-to-use checklist combining the above five components, which may help existing and potential long-term investors, research scholars, and industry make risk decisions related to investments. 
11.3 Research Objectives:

(1) To investigate accounting information as a critical risk determinant to establish predictability of Indian equities (both Index and Sector).

(2) To further investigate by including macro-economic factors impacting predictability of Indian equities (both Index and Sector).

(3) To investigate and rank type of businesses models, competitive landscape (stocks) which make returns more predictable.

(4) To Forecasting using ML and Deep learning algorithms and presenting a comparative analysis to demonstrate strength and accuracy.

(5) To provide an indicative checklist of various risk determinants and biases to support investment decisions.

\subsection{Proposed Methodology: \\ Study Population:}

The Study will include stocks listed on Bombay and National Stock exchange in India across different sectors for studying accounting, macro-economic and market-based risk determinants to compare their ability to forecast stocks return on a long-term basis. Such population and examination of samples from such population will inform the population for the selection of ML, AI, and Deep Learning models for predicting or forecasting stock prices and finally presenting a checklist of risk determinants.

\section{Study Sample:}

This study will be focused on findings from a finite population of stocks and ML techniques as outlined above in the Indian context. Therefore, samples for the study will be ascertained by applying a relevant statistic to ensure it represents the stock population across multiple sectors based on evaluating risk determinants and ML models.

\section{Study Instruments:}

The determinants are determined based on analysis of secondary financial and economic data and investigation of the relationship between stock returns and properties of various risk determinants. Various instruments and tools proposed to be utilized for this study includes

(a) Descriptive Statistics of risk determinants including Mean, Median, range (min-,max), Standard Deviation, Kurtosis, and Skewness of risk determinants and stock returns.

(b) Correlation analysis of stock returns and risk determinants

(c) Econometric models including normality test, stationarity test, Heteroscedasticity Test

(d) Forecasting models Linear, Nonlinear, and Hybrid models to forecast stocks and indexes' equity performance. The existing work in the literature on stock price prediction may broadly be grouped under OLS or simple Regressing, Panel data Methods, Timeseries Models (such as ARIMA), Granger Causality)

E-View, R-Studio, Python, and MS-Excel are the critical instruments proposed to be utilized for this study

\section{Study Procedure:}

The preliminary Model based on analysis of secondary data and literature review will be backtested using R and Python "train and test" and will be modified to enhance based on developing a suitable easy-to-use checklist to support risk decisions by investors.

\section{Analysis and Interpretation from Study:}

Data collected from secondary sources will be tested using appropriate statistical tests and ML techniques. Once interpreted based on scientific and experiential inferences, the outcomes will be presented in the form of a guiding checklist for illustrative.

\subsection{Results and Findings from Study:}


Results and Findings from the outcome will be published through an easy-to-use checklist to support decision making, comparative tables, process flow diagrams (including decision trees), and figurative representations for scholarly depictions.

\subsection{Conclusion and Implications of Study:}

The conclusion will expand the significance of findings and tools made available to investors to make informed risk decisions and will provide a methodology for considering accounting, macro-economic and other factors before taking investment decisions. The conclusion will also provide evidence of how effectiveness of ML application may be enhanced by selecting the stock and index in more structured manner and thereby provide comparative analysis of strength of technique for stock and index with certain characteristics.

\subsection{Study Limitations and Constraints:}

The Proposal is bound by time and has made subjective and discretionary assessments of risk determinants to develop a checklist. The risk cannot be entirely objective and is influenced by the individual perception of risk, and therefore the checklist and tool kit proposed from the study may not be suitable for adoption for all the investors or in different timeframes. Variations in the Suitability of risk timeframe and return objectives may vary from individual to individual and from time to time for the same individual. The research proposal is subject to limitations of accessing the investors' primary data at various age groups, risk preferences, and investment motivations. The study, therefore, makes assumptions based on available secondary data. Investment in equities requires assessing the company's future and, therefore, a confluence of different skills, including Finance, Economy, Management, Industry, and entrepreneurial vision. The research work output cannot and should not be used as investment advice or stock recommendation to buy, sell, or otherwise make an equities-related decision.

\section{ABCD ANALYSIS OF RESEARCH PROPOSAL:}

$\mathrm{ABCD}$ analysis is a modern and robust model to assess and evaluate concepts, ideas, technology, phenomena, decisions, or business models [79], [80]. Therefore, the ABCD analysis evaluates and provides a measure of success and critical considerations of proposals before implementing or adopting the proposal by various stakeholders. The study stakeholders are identified as investors, industry professionals, and future researchers in finance, wealth management, and machine learning.

\section{Advantages to Investors, Practitioners, and future researches:}

(1) The Proposal developed above works to link up to five key components which impact investment decisions, i.e., Accounting information and ratios, Macroeconomic indicators, Eco-system, and competition in which a business operates, forecasting, cognitive psychology, illusions, and bias.

(2) The Study Proposal is Universal for investors at different ages and life stage, i.e., it helps provide investors with a framework to make decisions

(3) The proposal is flexible and considers potential risk preferences for investors to make informed decisions

(4) The Proposal has the potential of studying the relationship between various risk determinants and returns inequities

Benefits to Investors, Practitioners, and future researches:

(1) The Proposal leverages risk determinants as an objective way to support subjective decisions and, therefore, serves as a tool kit

(2) The Study embraces cross-functional collaboration as the study is a confluence of finance, economics, statistics, and computer science, thereby promote cooperation and supports University Academia, Industry, and investors.

(3) The Proposed Study shall benefit investors at different life stages to not just decide but also to validate decisions made

(4) The framework provides an easy to use a checklist for investors who serve as a tool kit for investors, practitioners, and researchers to determine essential risk determinants in the process of investment or selection of stock for machine learning techniques 
Constraints toward Investors, Practitioners, and future researches:

(1) The Proposal is bound by time and has made subjective and discretionary assessments of risk determinants to develop a checklist.

(2) The risk cannot be entirely objective and is influenced by the individual perception of risk, and therefore the checklist and tool kit proposed from the study may not be suitable for adoption for all the investors or in different timeframes. Variations in the Suitability of risk timeframe and return objectives may vary from individual to individual and from time to time for the same individual.

(3) The research proposal is subject to limitations of accessing the investors' primary data at various age groups, risk preferences, and investment motivations. The study, therefore, makes assumptions based on available secondary data.

(4) Investment in equities requires assessing the company's future and, therefore, a confluence of different skills, including Finance, Economy, Management, Industry, and entrepreneurial vision.

(5) The research work output cannot and should not be used as investment advice or stock recommendation to buy, sell, or otherwise make an equities-related decision.

Disadvantages applicable to Investors, Practitioners, and future researches:

(1) Changes in market structure and maturity of equities market pose a threat to the causation and effect of Proposal.

(2) The Proposal focuses only on equities. The wealth creation process requires an approach to consider various asset class and relationship functions of portfolio optimizations.

(3) The proposal is subject to personal biases, e.g., more dominant risk preference of researcher and biases and equity related investment experience

13. SUGGESTIONS TO IMPLEMENT RESEARCH ACTIVITIES ACCORDING TO PROPOSAL :

(1) Determine Study Population

This study's population is identified as the equities listed on NSE and BSE, i.e., the Indian stock exchange.

(2) Develop and Adopt Study Methods and Methodology

To explore the characteristics of risk determinants and their relationship with stock return and predictability characteristics, Descriptive Statistics including Mean, Median, range (min-,max), Standard Deviation, Kurtosis, and Skewness of risk determinants and stock returns, Correlation analysis of stock returns and risk determinants, Econometric models including normality test, stationarity test, Heteroscedasticity Test and ) Forecasting models Linear, Nonlinear, and Hybrid models to forecast stocks and indexes' equity performance.

\section{(3) Perform and Collect Data}

Data for the study from secondary sources, including company websites, published financial statements, NSE and BSE, and Reserve Bank of India data repositories, would be collected through various suitable research instruments outlined in this paper.

\section{(4) Execute Data Analysis}

Data Analysis to include Descriptive Statistics including Mean, Median, range (min-,max), Standard Deviation, Kurtosis, and Skewness of risk determinants and stock returns, Correlation analysis of stock returns and risk determinants, Econometric models including normality test, stationarity test, Heteroscedasticity Test and ) Forecasting models Linear, Nonlinear, and Hybrid models to forecast stocks and indexes' equity performance

\section{(5) Result Interpretation and Conclusions}


Results and Findings from the outcome will be published through an easy-to-use checklist to support decision making, comparative tables, process flow diagrams (including decision trees), and figurative representations for scholarly depictions.

\section{(6) References and Bibliography}

Related research studies and publications, industry publications, and books will be referenced and quoted to support, substantiate, and solidify the conclusions drawn in this study, including suggestions outlined through the study's conclusion.

\section{CONCLUSION :}

The review of the literature identifies five critical risk determinants, i.e., Behavioral, Accounting, Macro-economic, Volatility, and Management theories and Forecasting and ML techniques for clustering, predictions, and classification to support risk decisions using different models, e.g., ARIMA, LSTM, VAR, Facebook Prophet, ARCH and GARCH family models, etc. which may significantly impact risk decisions. The concept of risk is highly subjective and is perceived by different investors differently; it is not always entirely objective and outside the beliefs, cognitive and socio-cultural considerations. However, examining the critical risk determinants would allow investors to make a more informed decision. An easy-to-use checklist to identify and assess these risk determinants may serve as a systematic framework for investors. It would also support future researchers both in finance and machine learning as one of the key reasons cited for failure of the stock prediction model is an arbitrary selection of stock, i.e., without considering risk determinant is impacting such selection. Most of the studies focused on Indian markets have considered only two or more and not all the five components identified through this Literature review. The Literature review also demonstrates that one of the critical reasons for the failure of ML stock prediction projects is an arbitrary selection of Stock or index for forecasting, i.e., ignoring accounting, macro, and other factors, ignoring individual Stock's impact on the portfolio, and deficient pre-processing of stock data. Further, based on our literature review of the Indian markets-related study, an opportunity to develop an easy-to-use checklist combining the study of the above five components may help existing and potential long-term investors, research scholars, and industry in making risk decisions related investments. The proposed study is not intended to make Stock or investment recommendations but to provide a systematic approach that an investor may adopt to make more risk-informed decisions or evaluate the investor's opportunity.

\section{REFERENCES :}

[1] Graham, B. and Dodd, D. L. Security Analysis: 6th Edition. 2008.

[2] Gephart, R. P. Van Maanen, J. and Oberlechner, T. (2009). Organizations and risk in late modernity. Organization Studies, 30(2/3), 143-144.

[3] Hermansson, H. (2012). Defending the Conception of "Objective Risk." Risk Analysis, 32(1), $16-24$.

[4] Markowitz, H. M. (1959). Portfolio Selection: Efficient Diversification of Investments. Yale University Press, 1(1), 1-368.

[5] Almamy, J. Aston, J. and Ngwa, L. N. (2016). An evaluation of Altman's Z-score using cash flow ratio to predict corporate failure amid the recent financial crisis: Evidence from the UK. Journal of Corporate Finance, 36(1), 278-285.

[6] Edward H. Bowman (1980). A Risk/Return Paradox for Strategic Management, Sloan Management Review, 21(3), 17-31.

[7] Fama, E. F. (1970). Efficient Capital Markets: A Review of Theory and Empirical Work. The Journal of Finance, 25(2), 383-417.

[8] Umoru, B. Udobi-Owoloja, P. I. Nzekwe, G. U. Iyiegbuniwe, W. C. and Ezike, J. E. (2020). Are Stock Returns Predictable? The Myth of Efficient Market Hypothesis and Random Walk Theory using Nigerian MArket Data. International Journal of Economics, Business and Management Research, 4(7), 115-130. 
[9] Bernoulli, D. (1738). Exposition of a New Theory on the Measurement of Risk (translated by Louise Sommer in Econometrica). Econometrica, 22(1), 23-36.

[10] Miller, K. D. and Bromiley, P. (1990). Strategic Risk and Corporate Performance: an Analysis of Alternative Risk Measures. Academy of Management Journal, 33(4), 756-779.

[11] Malhotra, N. and Tandon, K. (2013). Determinants of Stock Prices: Empirical Evidence from NSE 100 Companies. IRACST-International Journal of Research in Management \& Technology, 3(3), 86-95.

[12] Geetha E., and Swaaminathan (2015). A study on the factors influencing stock price: A Comparative study of Automobile and Information Technology Industries stocks in India. International Journal of Current Research and Academic Review, 3(3), 97-109.

[13] Islam, N. (1995). Growth empirics: A panel data approach, Quarterly Journal of Economics, 110(4), 1127-1171.

[14] Senyigit, Y. B. and Ag, Y. (2014). Explaining the Cross Section of Stock Returns: A Comparative Study of the United States and Turkey, Procedia - Social and Behavioral Sciences, 109(1), $327-332$.

[15] Hilkevics, S. and Semakina, V. (2019). The classification and comparison of business ratios analysis methods. Insights into Regional Development, 1(1), 47-56.

[16] Jermsittiparsert, K. Ambarita, D. E. Mihardjo, L. W. W. and Ghani, E. K. (2019). Risk-return through financial ratios as determinants of stock price: A study from ASEAN region. Journal of Security and Sustainability Issues, 9(1), 199-210.

[17] Granger, C. W. J. (1992). Forecasting stock market prices: Lessons for forecasters. International Journal of Forecasting, 8(1), 3-13.

[18] Wang, B. (2019). The cash conversion cycle spread. Journal of Financial Economics, 1(1), 157.

[19] Nobanee, H. Abdullatif, M. and Alhajjar, M. (2011). Cash conversion cycle and firm's performance of Japanese firms. Asian Review of Accounting, 19(9), 147-156.

[20] Shen, C. H. and Lin, K. L. (2010). The impact of corporate governance on the relationship between fundamental information analysis and stock returns. Emerging Markets Finance and Trade, 46(5), 90-105.

[21] Alessandri, T. M. and Khan, R. H. (2006), Market performance and deviance from industry norms: (Mis)alignment of organizational risk and industry risk. Journal of Business Research, 59(1), 1105-1115.

[22] Ravinder, D. D. and Anitha, M. (2013). Financial Analysis - A Study, IOSR Journal of Economics and Finance, 2(3), 10-22.

[23] Altman, E. I. (1968). Financial Ratios, Discriminant Analysis and the Prediction of Corporate Bankruptcy. The Journal of Finance, 23(1), 589-609.

[24] Barnes, P. (1987). The Analysis and Use of Financial Ratios: A Review Article. Journal of Business Finance \& Accounting, 14(4), 449-461.

[25] Ohlson, J. A. (1980). Financial Ratios and the Probabilistic Prediction of Bankruptcy. Journal of Accounting Research, 18(1), 109-131.

[26] Agusman, A. Monroe, G. S. Gasbarro, D. and Zumwalt, J. K. (2008). Accounting and capital market measures of risk: Evidence from Asian banks during 1998-2003. Journal of Banking and Finance, 32(1), 480-488.

[27] Elgers, P. T. (1980). Accounting-based risk predictions: A re-examination. The Accounting Review, 55(3), 389-408.

[28] Agarwal, V. and Taffler, R. (2008). Comparing the performance of market-based and 
accounting-based bankruptcy prediction models. Journal of Banking and Finance, 32(1), 15411551.

[29] Anshika (2017). Micro-economic factors affecting stock returns: An empirical study of S\&P BSE Bankex companies. Indian Journal of Economics and Development, 5(2), 1-6.

[30] Kiruba, A. S. and Vasantha, S. (2020). The Impact of Accounting ratios on Stock Returns: The Case of India's Chemical Industry. Adalya Journal, 9(1), 362-371.

[31] Ahmed, S. (2008). Aggregate Economic Variables and Stock Markets in India. International Research Journal of Finance and Economics, 1(14), 141-164.

[32] Gunu, U. and Idris, I. (2009). Environmental Factors Influencing Fluctuation of Share Prices on Nigeria Stock Exchange Market. An International MultiDisciplinary Journal, Ethiopia, 3(5), 199-212.

[33] BHULlAR, P. S. and Bhatnagar, D. (2020). Bitcoins as a determinant of stock market movements: A comparison of Indian and Chinese Stock Markets. Theoretical and Applied Economics, 3(364), 193-202.

[34] Gulati, D. and Kakhani, M. (2012). Relationship Between Stock Market and Foreign Exchange Market in India: An Empirical Study. Pacific Business Review International, 5(5), 66-71.

[35] Li, R. Li, S. Yuan, D. and Yu, K. (2020). Does economic policy uncertainty in the U.S. influence stock markets in China and India? Time-frequency evidence Author \& abstract. Applied Economics, Taylor \& Francis Journals, 52(39), 4300-4316.

[36] Sharma, G. D. and Mahendru, M. (2010). Impact of Macro-Economic Variables on Stock Prices in India. Global Journal of Management and Business Research, 10(7), 1-18.

[37] Olweny, T. and Omondi, K. (2011). The effects of macro-economic factors on stock return volatility in the Nairobi Stock Exchange, Kenya. Economics and Finance Review, 1(10), 3448.

[38] Hosseini, S. M. Ahmad, Z. and Lai, Y. W. (2011). The Role of Macroeconomic Variables on Stock Market Index in China and India. International Journal of Economics and Finance, 3(6), 233-243.

[39] Alam, M. N. Alam, M. S. and Chavali, K. (2020). Stock market response during COVID-19 lockdown period in India: An event study. Journal of Asian Finance, Economics and Business, 7(7), 131-137.

[40] Chellaswamy, K. P. Natchimuthu, N. and Faniband, M. (2020). Stock market sensitivity to macroeconomic factors: Evidence from China and India. Asian Economic and Financial Review, 10(2), 146-159.

[41] Thanh, S. D. Canh, N. P. and Maiti, M. (2020). Asymmetric effects of unanticipated monetary shocks on stock prices: Emerging market evidence. Economic Analysis and Policy, 65(C), 4055.

[42] Parab, N. Naik, R. and Reddy, Y. V. (2020). The impact of economic events on stock market returns: Evidence from India. Asian Economic and Financial Review, 10(11), 1232-1247.

[43] Baranidharan, S. and Dhivya, N. (2020). Causal Influence of Macroeconomics Factors Shock on Indian Stock Market: Evidence from BSE Index. Finance and Management, 2(2), 39-48.

[44] Wang, Z. Sun, Y. and Li, P. (2014). Functional principal components analysis of shanghai stock exchange 50 index. Discrete Dynamics in Nature and Society, 4(3), 1-7.

[45] Hargreaves, C. A. and Mani, C. K. (2015). The Selection of Winning Stocks Using Principal Component Analysis. American Journal of Marketing Research, 1(3), 183-188.

[46] E.S, D. S. Antony, J. and P, N. K. (2020). Is CAPM Still Alive for Sensex Stocks in Indian Stock Market? - an Empirical Analysis. International Journal of Management, 11(4), 210-220.

Pradeep Kumar Rangi, et al, (2021); www.srinivaspublication.com 
[47] Gardner, J. C. McGowan, Jr, C. B. and Moeller, S. E. (2012). Valuing Coca-Cola Using The Free Cash Flow To Equity Valuation Model. Journal of Business \& Economics Research (JBER), 10(11), 629-636.

[48] Nathan, R. G. Miller, M. and Hamel, P. (1988). Investment Planning After The Crash: A Fresh Look At The Power of Compunding. The CPA Journal, 58(6), 86-86.

[49] Fitzherbert, R. (2002). Continious Compunding, Volatility and The Equity Premium. Joint Institute of Actuaries and Faculty of Actuaries' Finance and Investment Conference, 1(1), 148.

[50] Rajgopal, S. Venkatachalam, M. and Kotha, S. (2002). Managerial Actions, Stock Returns, and Earnings: The Case of Business-to-Business Internet Firms. Wiley Online Library Journal of Accounting Research, 40(2), 529-556.

[51] Taleb, N. N. (2018). Skin in the Game: Hidden Asymmetries in Daily Life. Book from Random House Publishers, 1(1), 1-304.

[52] Finkle, T. A. (2017). Warren E. Buffett: Entrepreneur, investor, and philanthropist. Journal of Business Cases and Applications, 19(1), 1-19.

[53] Sheela, S. C. and Karthikeyan, D. K. (2012). Financial Performance of Pharmaceutical Industry in India using Du Pont Analysis. European Journal of Business and Management, 4(14), 8491.

[54] Little, P. L. Mortimer, J. W. Keene, M. A. and Henderson, L. R. (2009). Evaluating the effect of recession on retail firms' strategy using DuPont method: 2006-2009. Journal of Finance and Accountancy, 1(1), 1-7.

[55] Dobbs, M. E. (2014). Guidelines for applying Porter's five forces framework: a set of industry analysis templates. Competitiveness Review, 24(1), 32-45.

[56] Charumathi, B. Suraj, E. S. and Nitha, K. P. (2020). Refining equity valuation models and developing an integrated model for Indian bank stocks using ANN. International Journal of Management, 11(3), 501-510.

[57] Mauboussin, M. J. and Callahan, D. (2013). Measuring the Moat Assessing the Magnitude and Sustainability of Value Creation. Credit Suisse - Global Financial Strategies, 1(1), 1-70.

[58] Jabłoński, M. (2018). Value Migration to the Sustainable Business Models of Digital Economy Companies on the Capital Market. Sustainability of Young Companies-Contemporary Trends and Challenges, 10(9), 1-42.

[59] Slywotzky, A. J. (1996). Value Migration: How to Think Several Moves Ahead of the Competition (Management of Innovation and Change). Harvard Business Review Press, 1(1), $1-327$.

[60] Chattopadhyay, A. Lyle, M. R. and Wang, C. C. Y. (2021). Connecting Expected Stock Returns to Accounting Valuation Multiples: A Primer. Harvard Business School Accounting \& Management Unit Working Paper SSRN Electronic Journal, 21(81), 1-18.

[61] Barbier, P. J. A. and Farfán, K. J. B. (2020). Emerging market stock valuation: new evidence from Peru, Economies, International Journal of Economic Policy in Emerging, 14(1), 39-65.

[62] Chutka, J. and Kramarova, K. (2020). Usage of P/E earning models as a tool for valuation of shares in condition of global market. EDP Sciences, 74(1), 1-8.

[63] Karampouzis, A. D. and Ginoglou, D. (2020). Another Case on Discounted FCF vs. P2S Valuation: Privately Held Food \& Drinks Firms in Greece. Review, Chinese Business, 19(1), 16-21.

[64] Frensidy, B. Pelealu, R. J. and Robiyanto, R. (2020). Analysis of Equity Valuation Models and Target Price Accuracy: An Evidence From Analyst Reports in Indonesia. SAGE Open, 10(4), $1-13$. 
[65] Chan, R. W. and Lui, B. C. (2011). EV/EBIT Ratio: The Best of Both Worlds. Better Investing, $1(1), 27-28$.

[66] Jiang, X. and Kang, Q. (2020). Cross-Sectional PEG Ratios, Market Equity Premium, and Macroeconomic Activity. SAGE Journal of Accounting, Auditing \& Finance, 35(3), 471-500.

[67] Ady, S. U. (2018). The Cognitive and Psychological Bias in Investment Decision-Making Behavior: (Evidence From Indonesian Investor's Behavior). Journal of Economics and Behavioral Studies, 10(1), 86-100.

[68] Mehtab, S. and Sen, J. (2020). Stock price prediction using convolutional neural networks on a multivariate timeseries. arXiv, 2(1), 1-7.

[69] Sidra, M. Sen, J. and Dutta, A. (2020). Stock price prediction using machine learning and LSTM-based deep learning models. Machine Learning and Metaheuristic Algorithms and Applications, 1(1), 1-18.

[70] Mallick, A. K. Mishra, A. K. and Vyas, I. (2020). Forecasting stock prices of five major commercial banks in India and stress testing: A multivariate approach. Journal of Public Affairs, 1(1), 1472-3891.

[71] Somasundaram, V. J. J. H. M. S. S. (2020). Machine Learning based comparison of financial forecasting methods. International Journal of Advanced Science and Technology, 29(7), 89028907.

[72] Pradhan, A. K. (2020). Forecasting Daily Equity Price Using Auto Regressive Integrated Moving Average (ARIMA) Model: An Application to Shirpur Gold Refinery Ltd. India. Abhigyan Foundation for Organisational Research \& Education, 37(4), 1-12.

[73] Mathur, N. and Mathur, H. (2020). Application of GARCH Models For Volatility Modelling of Stock Market Returns: Evidences From BSE India, In Proceedings of Business and Management Conferences (No. 10112533). International Institute of Social and Economic Sciences. 1-19.

[74] Meher, B. K. Hawaldar, I. T. Spulbar, C. and Birau, R. (2021). Forecasting stock market prices using mixed ARIMA model: A case study of Indian pharmaceutical companies. Investment Management and Financial Innovations, 18(1), 42-54.

[75] Ding, S. Cui, T. Xiong, X. and Bai, R. (2020). Forecasting stock market return with nonlinearity: a genetic programming approach. Journal of Ambient Intelligence and Humanized Computing, 11(1), 4927-4939.

[76] Li, A. W. and Bastos, G. S. (2020). Stock Market Forecasting Using Deep Learning and Technical Analysis: A Systematic Review. IEEE Access, 8(1), 185232-185242.

[77] Mazed, M. (2019). Stock Price Prediction Using Time Series Data. Brac University, 1(1), 1-51.

[78] Chatfield, C. and Xing, H. The Analysis of Time Series: An Introduction with R. 2019.

[79] Aithal, P. S., Shailashree, V.T. \& Suresh Kumar, P. M. (2015). A New ABCD Technique to Analyse Business Models \& Concepts. International Journal of Management, IT and Engineering (IJMIE), 5(4), 409 - 423.

[80] Aithal, P. S. (2015). Study on ABCD Analysis Technique for Business Models, business strategies, Operating Concepts \& Business Systems. International Journal in Management and Social Science, 4(1), 98-115.

[81] GÜREL, E. (2017). Swot Analysis: A Theoritical Review. Journal of International Social Research, 10(51), 1-13.

[82] Ghazinoory, S. Abdi, M. and Azadegan-Mehr, M. (2011). Swot methodology: A state-of-theart review for the past, a framework for the future. Journal of Business Economics and Management, 12(1), 24-48. 
[83] Sharpe, W. F. (1964). Capital Asset Prices: A Theory of Market Equilibrium under Conditions of Risk. The Journal of Finance, 19(1), 425-442.

[84] Arroyave, J. (2018). A comparative analysis of the effectiveness of corporate bankruptcy prediction models based on financial ratios: Evidence from Colombia. Journal of International Studies, 11(1), 273-287.

[85] Youn, H. and Gu, Z. (2010). Predicting Korean lodging firm failures: An artificial neural network model along with a logistic regression model. International Journal of Hospitality Management, 29(1), 120-127.

[86] Tang, T. C. and Chi, L. C. (2005). Neural networks analysis in business failure prediction of Chinese importers: A between-countries approach. Expert Systems with Applications, 29(1), 244-255.

[87] Baltagi, B. Econometric analysis of panel data. 2005.

[88] Box, G. E. P. Jenkins, G. M. Reinsel, G. C. and Ljung, G. M. (1970). Time Series Analysis: Forecasting and Control. 1970.

[89] Ahmed, R. and Saravanaraj, M. G. (2016). A Study on Factors Influencing Buying Behaviour in Indian Stock Markets. SNS Journal Of Marketing, 7(1), 1-9.

[90] Ritter, J. R. (2003). Behavioral finance. Pacific Basin Finance Journal, 11(4), 429-437.

[91] Tversky, A. and Kahneman, D. (1974). Judgment under uncertainty: Heuristics and biases. Science, 185(4157), 1124-1131.

[92] Filbeck, G. Hatfield, P. and Horvath, P. (2005). Risk Aversion and Personality Type. Journal of Behavioral Finance, 6(4), 170-180.

[93] Luong, L. P. and Ha, D. T. T. (2011). Behavioral Factors Influencing Individual Investors' Decision-Making and Performance: A Survey at the Ho Chi Minh Stock Exchange. Umea: Umea Universitet, 1(1), 1-114.

[94] Markowitz, H. M. (1952). Portfolio Selection. The Journal of Finance, 7(1), 77-91.

[95] Rusdiyanto, R. and Narsa, I. M. (2019). The Effects of Earnings Volatility, Net Income and Comprehensive Income on Stock Prices on Banking Companies on the Indonesia Stock Exchange. International Review of Management and Marketing, 9(6), 18-24.

[96] Mauboussin, M. and Johnson, P. (1997). Competitive Advantage Period: The Neglected Value Driver. Financial Management, 26(2), 67-74.

[97] Chauhan, Y. Mishra, A. K. and Spahr, R. W. (2020). Stock pledging and firm risk: Evidence from India. Financial Management, 1(1), 1- 20.

[98] Gupta, A. and Arya, P. K. (2020). Impact of splits on stock splits ratios around announcement day: Empirical evidence from india. Investment Management and Financial Innovations, 17(3), 345-359.

[99] Jawed, M. S. and Kotha, K. K. (2020). Stock Liquidity and Firm Value: Evidence from a Policy Experiment in India. International Review of Finance, 20(1), 215-224.

[100] Hegde, S. Seth, R. and Vishwanatha, S. R. (2020). Ownership concentration and stock returns: Evidence from family firms in India. Pacific Basin Finance Journal, 61(C), 1-25.

[101] Engle, R. F. (1982). Autoregressive Conditional Heteroscedasticity with Estimates of the Variance of United Kingdom Inflation. Econometrica, 50(4), 987-1007.

[102] Bollerslev, T. (1986). Generalized autoregressive conditional heteroskedasticity. Journal of Econometrics, 31(3), 307-327.

[103] Bandivadekar, S. and Ghosh, S. (2003). Derivatives and volatility on Indian stock markets. Reserve Bank of India Occasional, 24(3), 187-201. 
[104] Premaratne, G. and Balasubramanyan, L. (2004). Stock Market Volatility: Examining North America, Europe and Asia. SSRN Electronic Journal, 1(1), 1-41.

[105] Apte, P. G. (2001). The Interrelationship between stock Markets and the foreign exchange market. Indian Institute of Management, 169(1), 1-24.

[106] Chakraborty, M. and Subramaniam, S. (2020). Asymmetric relationship of investor sentiment with stock return and volatility: evidence from India. Review of Behavioral Finance, 12(4), 435454.

[107] Mirza, A. Malek, M. and Abdul-Hamid, M. A. (2018). Value Relevance of Earnings and Book Value of Equity: Evidence from Malaysia. Global Business Management Review, 10(2), 19-40.

[108] Damodaran, A. (2007). Return on Capital (ROC), Return on Invested Capital (ROIC) and Return on Equity (ROE): Measurement and Implications. SSRN Electronic Journal, 1(1), 1-69.

[109] Durán-Vázquez, R. Lorenzo-Valdés, A. and Castillo-Ramírez, C. E. (2014). Effectiveness of corporate finance valuation methods: Piotroski score in an Ohlson model: The case of Mexico. Journal of Economics, Finance and Administrative Science, 19(37), 104-107.

[110] Epstein, R. C. (1925). Industrial profits in 1917. Quarterly Journal of Economics, 39(2), 241266.

[111] Lutz, F. A. The theory of interest. 2017.

[112] Hirshleifer, J. (1958). On the Theory of Optimal Investment Decision. Journal of Political Economy, 66(4), 329-352.

[113] Weston, J. F. and Gordon, M. J. The Investment, Financing, and Valuation of the Corporation. 1963.

[114] Miller, M. H. and Modigliani, F. (1961). Dividend Policy, Growth, and the Valuation of Shares. The Journal of Business, 34(4), 411-433.

[115] Kyriazis, D. and Anastassis, C. (2007). The validity of the economic value added approach: An empirical application. European Financial Management, 13(1), 71-100. 